\title{
Symbiotic characters, thermal requirement, growth, yield and economics of pigeonpea (Cajanus cajan) genotypes sown at different dates under Punjab conditions
}

\author{
Guriqbal Singh*, Harpreet Kaur, Navneet Aggarwal, Hari Ram, K. K. Gill and Veena \\ Khanna \\ Department of Plant Breeding and Genetics, Punjab Agricultural University, Ludhiana, Punjab- 141004, INDIA \\ *Corresponding author. E-mail: singhguriqbal@pau.edu
}

Received: July 12, 2015; Revised received: November 24, 2015; Accepted: March 9, 2016

\begin{abstract}
A field experiment was conducted during kharif (rainy season) 2008 and 2009 at research farm of the Punjab Agricultural University, Ludhiana, to study the effect of four/three sowing dates (1 May, 15 May, 1 June and 15 June in 2008 and 15 May, 1 June and 15 June in 2009) on the symbiotic characters, thermal requirement, growth, productivity and economics of four pigeonpea genotypes (AL 201, AL 1507, AL 1578 and AL 1593). Days taken to $50 \%$ flowering, physiological maturity, and various agroclimatic indices i.e. AGDD, AHTU, APTU and HUE decreased with delay in sowing. The crop sown on 15 May recorded the highest nodule dry weight plant ${ }^{-1}$. The grain yield was significantly higher for the 15 May sowing compared to the 15 June sowing. During the two years, the crop sown on 15 May registered on average 6.7 and 48.0 percent higher grain yield than the 1 June and 15 June sowings, respectively. The crop sown on 15 May gave the maximum gross returns, net returns and benefit-cost $(B: C)$ ratio. Among the genotypes, $A L 1507$ recorded the highest nodule number plant ${ }^{-1}$ and $A L 1578$ recorded the maximum nodule dry weight plant ${ }^{-1}$. Genotypes $\mathrm{AL} 1507, \mathrm{AL} 1578$ and $\mathrm{AL} 1593$ registered on average 19.4, 19.2 and 20.0 percent higher grain yield relative to AL 201, respectively. The genotype AL 1507 in 2008 and AL 1593 in 2009 performed better in terms of heat use efficiency for grain yield.
\end{abstract}

Keywords: Agroclimatic indices, Economics, Genotypes, Nodulation, Sowing dates

\section{INTRODUCTION}

Pigeonpea [Cajanus cajan (L.) Millsp.] is well adapted to arid and semi-arid climates of the tropical and subtropical regions of the world (Rao et al. 2003). Pigeonpea is a leguminous crop that has been cultivated for human consumption and many other uses in many parts of the world. During 2012-13, in India, it was cultivated on an area of 3.69 million hectares with a production of 2.75 million tonnes and productivity of $753 \mathrm{~kg} \mathrm{ha}^{-1}$ (INDIASTAT, 2014). It contains high level of proteins and important amino acids such a methionine, lysine and tryptophan. Sowing time, a nonmonetary input, has considerable influence on growth and yield of pigeonpea crop (Wilson et al. 2012, Egbe et al. 2013). Sowing at the optimum time gives higher yields due to suitable weather conditions that prevail at all the growth stages. Early sown crop may accumulate excessive dry matter resulting in reduced pod development, while late sown crop may have less biomass accumulation and consequently reduced yields. Delayed sowings beyond the optimum period result in low grain yields of pigeonpea (Kumar et al. 2008). In addition, genotypes may vary in productivity (Singh
2006, Egbe and Vange 2008, Bhavi et al. 2013, Umesh et al. 2013) and the yield potential of the genotypes can be fully exploited by providing appropriate microclimate temperature at different growth and development phases.

Earlier, the recommended time of sowing of pigeonpea in Punjab state was the first fortnight of June. However, with the changing climate, the optimum time of sowing may vary. Furthermore, when the crop is sown during first fortnight of June, many times the maturity of the crop is delayed (Ram et al. 2011), causing delayed harvesting of pigeonpea and consequently delayed sowing of succeeding wheat crop and ultimately low productivity (Tomar et al. 2014). Moreover, long duration genotypes produce higher yield than early maturing genotypes, but they take more time to mature which may delay the sowing of succeeding crop. Performance of new genotypes under different sowing time needs to be tested. Keeping these factors in mind, the present experiment was conducted to study the effect of sowing time on the symbiotic parameters, thermal requirement, growth, yield and economics of pigeonpea genotypes under Punjab conditions. 


\section{MATERIALS AND METHODS}

A field experiment was conducted during kharif (rainy season) 2008 and 2009 at the research farm of the Punjab Agricultural University, Ludhiana $\left(30^{\circ} 54^{\prime} \mathrm{N}, 75^{\circ}\right.$ $48^{\prime} \mathrm{E}$, altitude $247 \mathrm{~m}$ ), India. The soil of the experimental site was low in organic carbon (0.36), low in available nitrogen, medium in available phosphorus $\left(17.5 \mathrm{~kg} \mathrm{ha}^{-1}\right)$ and potassium $\left(152 \mathrm{~kg} \mathrm{ha}^{-1}\right)$ with a $\mathrm{pH}$ of 8.4. During the crop growing season, total 975.3 and $818.0 \mathrm{~mm}$ of rainfall was received during 2008 and 2009, respectively. The experiment was laid out in split-plot design with four replications. The treatments included four/three dates of sowing (1 May, 15 May, 1 June and 15 June in 2008 and 15 May, 1 June and 15 June in 2009) in main plots and four genotypes (AL 201, AL 1507, AL 1578 and AL 1593) in sub plots. Nutrients viz. $15 \mathrm{~kg}$ nitrogen and $40 \mathrm{~kg} \mathrm{P}_{2} \mathrm{O}_{5}$ ha $^{-1}$ were applied entirely as basal dose to the crop and the crop was sown in rows $50 \mathrm{~cm}$ apart using a seed rate of 15 $\mathrm{kg} \mathrm{ha}{ }^{-1}$. Each sub plot measured $6.0 \mathrm{~m} \times 2.5 \mathrm{~m}$. Weeds were controlled by pendimethalin (Stomp 30 EC) @ $0.45 \mathrm{~kg} \mathrm{ha}^{-1}$ as pre-emergence spraying 500 litres of water followed by hand weeding six weeks after sowing. The crop was raised with the recommended package of practices (PAU 2008).

Days taken to $50 \%$ flowering and maturity were recorded for each genotype sown on different dates. Growing degree days (or heat units) were determined as per Nuttonson (1955):

$\mathrm{GDD}=\left(\frac{\text { Tmax }+\mathrm{Tmin}}{2}\right)-\mathrm{T}_{\mathrm{b}}$

Where,

Tmax, maximum temperature $\left({ }^{\circ} \mathrm{C}\right)$ during a day

Tmin, minimum temperature $\left({ }^{\circ} \mathrm{C}\right)$ during a day
$\mathrm{Tb}$, base temperature of $10.0{ }^{\circ} \mathrm{C}$

Heliothermal units (HTU), the product of GDD and corresponding actual sunshine hours for that day, were computed on daily basis as follows:

HTU $=$ GDD $\times$ Actual sunshine hours

Photothermal units (PTU), the product of GDD and corresponding day length for that day, were computed on daily basis as follows:

$\mathrm{PTU}=\mathrm{GDD} \times$ Day length

where day length refers to maximum possible sunshine hours.

Heat use efficiency $($ HUE $)=$ Grain yield $\left(\mathrm{kgha}^{-1}\right) /$ Accumulated GDD (heat units) $\left({ }^{\circ} \mathrm{C}\right.$ day)

Growing degree days, heliothermal units and photothermal units were accumulated from the date of sowing to $50 \%$ flowering and maturity to give accumulated indices. Heat use efficiency was calculated after harvesting of the crop.

Five plants plot $^{-1}$ were randomly selected for counting nodules and nodule weight. These plants were uprooted 45 days after sowing (DAS). After counting, the nodules were dried in an oven at $60{ }^{\circ} \mathrm{C}$. Data on plant height, branches plant ${ }^{-1}$ and pods plant ${ }^{-1}$ were recorded at harvest from randomly selected five plants from each plot. Biological yield and grain yield were recorded on per plot basis and then converted into $\mathrm{kg} \mathrm{ha}^{-1}$. Grainspod $^{-1}$ were recorded from 20 pods. The data on 100-grain weight were recorded after taking 100 randomly selected grains. Harvest index was calculated by dividing grain yield by biological yield and multiplied by 100 . Gross returns, net returns as well as benefit:cost (B:C) ratio were also estimated using prevailing prices of input and output. Data were subjected to analysis of variance (ANOVA) in a split-plot design as per the standard procedure.

Table 1. Effect of dates of sowing and genotypes on different agroclimatic indices (GDD, HTU, PTU) and heat use efficiency of pigeonpea at $50 \%$ flowering and physiological maturity.

\begin{tabular}{|c|c|c|c|c|c|c|c|c|c|c|}
\hline \multirow[b]{2}{*}{ Year } & \multirow[b]{2}{*}{ Treatment } & \multicolumn{4}{|c|}{$50 \%$ flowering } & \multicolumn{5}{|c|}{ Physiological maturity } \\
\hline & & DAS & $\begin{array}{c}\text { AGDD } \\
\left({ }^{\circ} \mathrm{C} \text { day }\right)\end{array}$ & $\begin{array}{c}\text { AHTU } \\
\left({ }^{\circ} \mathrm{C} \text { day }\right)\end{array}$ & $\begin{array}{c}\text { APTU } \\
\left({ }^{\circ} \mathrm{C} \text { day }\right)\end{array}$ & DAS & $\begin{array}{c}\text { AGDD } \\
\left({ }^{\circ} \mathrm{C} \text { day }\right)\end{array}$ & $\begin{array}{c}\text { AHTU } \\
\left({ }^{\circ} \mathrm{C} \text { day }\right)\end{array}$ & $\begin{array}{c}\text { APTU } \\
\left({ }^{\circ} \mathrm{C} \text { day }\right)\end{array}$ & $\begin{array}{c}\text { HUE (kg ha }{ }^{-10} \mathrm{C}^{-1} \\
\text { day) }\end{array}$ \\
\hline \multirow[t]{10}{*}{2008} & \multicolumn{10}{|c|}{ Date of Sowing } \\
\hline & 1 May & 111 & 2222 & 14854 & 30723 & 159 & 3099 & 22317 & 41615 & 0.47 \\
\hline & 15 May & 104 & 2083 & 13686 & 28760 & 153 & 2942 & 20826 & 39225 & 0.55 \\
\hline & 1 June & 98 & 1965 & 13246 & 26903 & 149 & 2802 & 19804 & 36816 & 0.56 \\
\hline & 15 June & 90 & 1769 & 12639 & 23986 & 145 & 2623 & 19055 & 33918 & 0.44 \\
\hline & \multicolumn{10}{|l|}{ Genotype } \\
\hline & AL 201 & 103 & 1981 & 13607 & 27085 & 155 & 2827 & 20142 & 37077 & 0.44 \\
\hline & AL 1507 & 98 & 1881 & 12609 & 25812 & 148 & 2743 & 19600 & 36136 & 0.55 \\
\hline & AL 1578 & 100 & 1932 & 13133 & 26460 & 151 & 2790 & 19913 & 36670 & 0.53 \\
\hline & AL 1593 & 102 & 1962 & 13412 & 26841 & 152 & 2796 & 19924 & 36728 & 0.53 \\
\hline \multirow[t]{9}{*}{2009} & \multicolumn{10}{|c|}{ Date of Sowing } \\
\hline & 15 May & 104 & 2249 & 18965 & 31076 & 153 & 3108 & 26027 & 41529 & 0.42 \\
\hline & 1 June & 99 & 2072 & 16832 & 28385 & 149 & 2869 & 23807 & 37825 & 0.41 \\
\hline & 15 June & 91 & 1834 & 14672 & 24892 & 143 & 2639 & 21600 & 34289 & 0.31 \\
\hline & Genotype & & & & & & & & & \\
\hline & AL 201 & 100 & 2078 & 17026 & 28449 & 150 & 2899 & 24016 & 38189 & 0.32 \\
\hline & AL 1507 & 96 & 2010 & 16488 & 27590 & 146 & 2845 & 23624 & 37588 & 0.39 \\
\hline & AL 1578 & 97 & 2039 & 16752 & 27952 & 147 & 2856 & 23697 & 37702 & 0.39 \\
\hline & AL 1593 & 100 & 2081 & 17026 & 28480 & 149 & 2886 & 23909 & 38045 & 0.41 \\
\hline
\end{tabular}




\section{RESULTS AND DISCUSSION}

Effect of date of sowing: Sowing date had a pronounced effect on days to $50 \%$ flowering and maturity of pigeonpea (Table 1). Days to $50 \%$ flowering and maturity decreased with delay in sowing.

Accumulated agroclimatic indices i.e. growing degree days, heliothermal units, photothermal units and heat use efficiency computed for different dates of sowing from days after sowing (DAS) to $50 \%$ flowering as well as physiological maturity are given in Table 1 . Early sowing required higher agroclimatic indices as compared to late sowing. Heat units for different phenological stages decrease with delay in sowing of kharif mungbean (Singh et al. 2010) and kharif urdbean (Singh et al. 2012). Higher heat units were accumulated for 50\% flowering and physiological maturity during 2009 than in 2008. With delay in sowing, lower agroclimatic indices were required and resulted in lowest heat units accumulation for the 15 June sowing as compared with May sowing. In general earlier sown crop availed more growing degree days and accumulated more dry matter than late sown crop. First and second dates of sowing accumulated more heat units, resulting in more heat use efficiencies as compared to third date of sowing.

The date of sowing did not affect the number of nodules plant ${ }^{-1}$ and nodule dry weight significantly (Table
2). During both years, plant height was significantly higher for the early sowing (1 May in 2008 and 15 May in 2009) than the other sowing dates, possibly due to longer period of vegetative growth. During 2008, 1 May sowing produced significantly higher branches plant $^{-1}$ than the other sowing dates. However, during 2009, 1 June sown crop significantly produced higher branches plant ${ }^{-1}$ than 15 May and 15 June sowing. Kumar et al. (2008) also reported reduced plant growth and yield attributes in case of delayed sowing.

The pods plant ${ }^{-1}$ is an important yield attributing character. The crop sown on 15 May recorded the highest number of pods plant ${ }^{-1}$ (Table 2). In 2008, the 15 May sown crop recorded significantly higher pods plant ${ }^{-1}$ than the 1 May and 15 June sown crop, which was statistically at par with 1 June sown crop. In 2009, however, the 15 May sown crop recorded significantly higher pods plant ${ }^{-1}$ than both June 1 and June 15 sown crops. The highest number of pods plant ${ }^{-1}$ in May 15 sown crop might be due to a better balance between vegetative and reproductive phases and sufficient time available for setting of pods. These findings are in agreement with those of Rani and Reddy (2010) reported for pigeonpea. The date of sowing did not affect the number of grains $\operatorname{pod}^{-1}$ and the 100-grain weight significantly.

The biological yield was significantly reduced with

Table 2. Effect of sowing dates and genotypes on nodulation, plant characters and yield attributes of pigeonpea.

\begin{tabular}{|c|c|c|c|c|c|c|c|c|c|c|c|c|c|c|}
\hline \multirow[t]{2}{*}{ Treatment } & \multicolumn{2}{|c|}{$\begin{array}{c}\text { Number of } \\
\text { nodules } \\
\text { plant }^{-1}\end{array}$} & \multicolumn{2}{|c|}{ 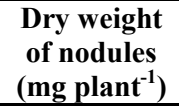 } & \multicolumn{2}{|c|}{$\begin{array}{l}\text { Plant height } \\
\text { (cm) }\end{array}$} & \multicolumn{2}{|c|}{$\begin{array}{l}\text { Branches } \\
\text { plant }^{-1}\end{array}$} & \multicolumn{2}{|c|}{ Pods plant $^{-1}$} & \multicolumn{2}{|c|}{ Grains pod ${ }^{-1}$} & \multicolumn{2}{|c|}{$\begin{array}{l}\text { 100-grain } \\
\text { weight (g) }\end{array}$} \\
\hline & 2008 & 2009 & 2008 & 2009 & 2008 & 2009 & 2008 & 2009 & 2008 & 2009 & 2008 & 2009 & 2008 & 2009 \\
\hline \multicolumn{15}{|c|}{ Date of sowing } \\
\hline 1 May & 10.0 & & 62.8 & & 222.4 & & 11.6 & & 105.2 & & 3.81 & & 6.98 & \\
\hline 15 May & 10.6 & 8.0 & 65.1 & 42.0 & 192.6 & 178.3 & 10.3 & 11.3 & 116.6 & 128.3 & 4.34 & 4.36 & 7.13 & 5.91 \\
\hline 1 June & 10.6 & 8.6 & 63.4 & 40.8 & 182.9 & 167.0 & 9.3 & 12.1 & 112.6 & 110.6 & 4.34 & 4.36 & 7.11 & 6.27 \\
\hline 15 June & 8.4 & 6.8 & 57.0 & 38.1 & 151.7 & 155.2 & 9.4 & 10.4 & 100.8 & 93.1 & 4.12 & 4.70 & 7.03 & 6.26 \\
\hline $\mathrm{CD}(\mathrm{p}=0.05)$ & NS & NS & NS & NS & 8.0 & 3.7 & 1.2 & 0.7 & 7.9 & 10.6 & NS & NS & NS & NS \\
\hline \multicolumn{15}{|l|}{ Genotype } \\
\hline AL 201 & 11.0 & 8.4 & 63.7 & 43.6 & 182.2 & 162.2 & 9.7 & 11.6 & 100.7 & 97.1 & 4.16 & 4.35 & 6.98 & 6.25 \\
\hline AL 1507 & 11.2 & 8.9 & 61.9 & 42.3 & 192.6 & 162.8 & 10.3 & 10.5 & 113.4 & 116.1 & 4.26 & 4.45 & 6.78 & 6.19 \\
\hline AL 1578 & 10.8 & 7.6 & 68.4 & 40.0 & 186.0 & 175.0 & 10.2 & 11.9 & 112.6 & 112.2 & 4.15 & 4.65 & 7.36 & 5.88 \\
\hline AL 1593 & 6.5 & 6.3 & 54.3 & 35.3 & 188.8 & 167.2 & 10.5 & 10.9 & 108.6 & 117.2 & 4.24 & 4.45 & 7.11 & 6.25 \\
\hline $\mathrm{CD}(\mathrm{p}=0.05)$ & 0.7 & 1.4 & 7.6 & NS & 6.7 & 3.9 & NS & 0.8 & 5.7 & 8.6 & NS & NS & NS & NS \\
\hline
\end{tabular}

Table 3. Effect of sowing dates and genotypes on the biological yield, grain yield and harvest index of pigeonpea.

\begin{tabular}{|c|c|c|c|c|c|c|}
\hline \multirow{2}{*}{ Treatment } & \multicolumn{2}{|c|}{ Biological yield $\left(\mathrm{kg} \mathrm{ha}^{-1}\right)$} & \multicolumn{2}{|c|}{ Grain yield $\left(\mathrm{kg} \mathrm{ha}^{-1}\right)$} & \multicolumn{2}{|c|}{ Harvest index (\%) } \\
\hline & 2008 & 2009 & 2008 & 2009 & 2008 & 2009 \\
\hline \multicolumn{7}{|c|}{ Date of sowing } \\
\hline 1 May & 8210 & & 1484 & & 18.1 & \\
\hline 15 May & 7160 & 7467 & 1609 & 1294 & 22.5 & 17.3 \\
\hline 1 June & 6384 & 6659 & 1555 & 1164 & 24.4 & 17.5 \\
\hline 15 June & 4450 & 5842 & 1148 & 814 & 25.8 & 13.9 \\
\hline $\mathrm{CD}(\mathrm{p}=0.05)$ & 747 & 680 & 159 & 62 & & \\
\hline \multicolumn{7}{|l|}{ Genotype } \\
\hline AL 201 & 6353 & 6633 & 1289 & 926 & 20.3 & 14.0 \\
\hline AL 1507 & 6429 & 6478 & 1523 & 1122 & 23.7 & 17.3 \\
\hline AL 1578 & 6741 & 6744 & 1516 & 1126 & 22.5 & 16.7 \\
\hline AL 1593 & 6683 & 6767 & 1469 & 1189 & 22.0 & 17.6 \\
\hline $\mathrm{CD}(\mathrm{p}=0.05)$ & NS & NS & 77 & 103 & & \\
\hline
\end{tabular}


Table 4. Effect of sowing dates and genotypes on economics of pigeonpea.

\begin{tabular}{|c|c|c|c|c|c|c|}
\hline \multirow{2}{*}{ Treatment } & \multicolumn{2}{|c|}{ Gross returns $\left(\mathrm{Rs} \mathrm{ha}^{-1}\right)$} & \multicolumn{2}{|c|}{ Net returns $\left(\mathrm{Rs} \mathrm{ha}^{-1}\right)$} & \multicolumn{2}{|c|}{$\mathrm{B}: \mathrm{C}$ ratio } \\
\hline & 2008 & 2009 & 2008 & 2009 & 2008 & 2009 \\
\hline \multicolumn{7}{|c|}{ Date of sowing } \\
\hline 1 May & 63812 & & 36242 & & 2.31 & \\
\hline 15 May & 69187 & 55642 & 41617 & 28072 & 2.51 & 2.02 \\
\hline 1 June & 66865 & 50052 & 39295 & 22482 & 2.43 & 1.82 \\
\hline 15 June & 49364 & 35002 & 21794 & 7432 & 1.79 & 1.27 \\
\hline \multicolumn{7}{|l|}{ Genotype } \\
\hline AL 201 & 55427 & 39818 & 27857 & 12248 & 2.01 & 1.44 \\
\hline AL 1507 & 65489 & 48246 & 37919 & 20676 & 2.38 & 1.75 \\
\hline AL 1578 & 65188 & 48418 & 37618 & 20848 & 2.36 & 1.76 \\
\hline AL 1593 & 63167 & 51127 & 35597 & 23557 & 2.29 & 1.85 \\
\hline
\end{tabular}

delay in sowing (Table 3). The grain yield was significantly higher for 15 May sowing than 15 June sowing date. The crop sown on 15 May registered 3.4 and 40.1 per cent higher grain yield in 2008 and 11.1 and 58.9 per cent higher grain yield in 2009 compared to the 1 June and 15 June sowings, respectively. Higher grain yield in early sowing (15 May) might be due to more pods plant ${ }^{-1}$ (Table 2). Ram et al. (2011) also reported that 15 May sown pigeonpea crop produced significantly higher grain yield than 1 June and 15 June sown crop. The increased grain yield due to early sowing is ascribed to the high leaf area index and its persistence, as well as higher photosynthetically active radiation interception and absorption, leading to higher dry matter accumulation before the attainment of the reproductive stage by the pigeonpea crop (Patel et al. 2000). Other researchers have also reported sharp decline in the grain yield of pigeonpea with delay in sowing (Kumar et al. 2008, Ram et al. 2011). In 2008, with delay in sowing harvest index increased whereas in 2009, 15 June sowing recorded the lowest harvest index, which could be due to variation in rainfall during the two years. Date of sowing $\times$ genotype interaction, with respect to grain yield, was found to be nonsignificant.

The crop sown on 15 May gave the highest gross returns, net returns and $\mathrm{B}: \mathrm{C}$ ratio (Table 4 ), which was due to higher grain yield. The 15 May sowing gave an additional income of Rs 2322 \& Rs 19823 per hectare in 2008 and Rs 5590 \& Rs 20640 per hectare in 2009 compared to those sown on 1 June and 15 June respectively. Reddy et al. (2012) also reported higher returns with early sowing of pigeonpea.

Performance of genotypes: Among the genotypes, AL 1507 took minimum days whereas AL 201 and AL 1593 took maximum days to $50 \%$ flowering and maturity (Table 1). The genotype AL 201 required the highest and AL 1507 required the lowest agroclimatic indices (AGDD, AHTU and APTU) to attain physiological maturity. During first year of study, AL 1507 and during second year, AL 1593 performed best in terms of heat use efficiency for grain yield, although the differences were quite small among genotypes AL 1507, AL 1578 and AL 1593. Genotype AL 201 had consistently low heat efficiency.

The highest nodule number plant ${ }^{-1}$ was observed in $\mathrm{AL}$ 1507 (Table 2). In 2008, AL 1578 recorded the highest nodule dry weight whereas in 2009, genotypic differences in terms of nodule dry weight were not significant. The genotypes AL 1507 and AL 1578 recorded the maximum plant height in 2008 and 2009, respectively, whereas AL 201 recorded the lowest plant height. The genotypes did not affect the branches plant ${ }^{-1}$ during 2008. In 2009, AL 1578 recorded significantly higher number of branches plant ${ }^{-1}$ than AL 1507 and AL 1593. The number of branches in AL 1578 was at par with AL 201.

AL 1507 and AL 1593 recorded the highest pods plant $^{-1}$ in 2008 and 2009, respectively (Table 2). The genotype AL 1507 recorded significantly higher pods plant $^{-1}$ than AL 201, which was, however statistically at par with AL 1578 and AL 1593 in 2008. In 2009, AL 1593 produced significantly higher pods plant ${ }^{-1}$ than AL 201 which was, however, statistically at par with AL 1507 and AL 1578. The grains pod ${ }^{-1}$ and 100-grain weight were not influenced significantly.

Genotypes did not differ significantly in biological yield during both the years of study (Table 3). In 2008, AL 1507 recorded significantly higher grain yield than AL 201 which was, however, at par with AL 1578 and AL 1593. In 2009, AL 1593 recorded significantly higher grain yield than AL 201 which was, however, at par with AL 1578 and AL 1507. On the basis of mean of two years, pigeonpea genotypes, AL 1507, AL 1578 and AL 1593 registered 19.4, 19.2 and 20.0 percent higher grain yield over AL 201, respectively. Other researchers also reported genotypic variation with respect to growth and yield of pigeonpea (Mligo and Craufurd 2005, Reddy et al. 2006, Singh 2006, Egbe and Vange 2008). During both the years, AL 201 recorded the lowest harvest index. The genotype AL 1507 in 2008 and AL 1593 in 2009 gave the maximum gross returns, net returns and B:C ratio (Table 4).

\section{Conclusion}

The crop sown on 15 May provided the highest grain yield (1609 and $1294 \mathrm{~kg} \mathrm{ha}^{-1}$ in 2008 and 2009, respectively) and net returns (Rs 41617 and $28072 \mathrm{ha}^{-1}$ in 
2008 and 2009, respectively). Genotypes AL 1507, AL 1578 and AL 1593 performed better in terms of grain yield and net returns. On the basis of this study, it can be concluded that under Punjab conditions, 15 May is the optimum time of sowing of pigeonpea and $\mathrm{AL}$ 1507, AL 1578 and AL 1593 are the most promising genotypes with respect to grain yield and economics.

\section{REFERENCES}

Bhavi R, Desai B.K. and Vinodakumar S.N. (2013). Effect of Planting Geometry on the Yield, Nutrient Availability and Economics of Pigeonpea Genotypes. Trends in Biosciences, 6(6): 773-775.

Egbe MO, Aku AA and Odebiyi S 2013.Effect of Planting Dates on the Performance of Pigeonpea Varieties in Southern Guinea Savanna Ecology of Nigeria. Journal of Biology, Agriculture and Healthcare 3(8):22-28.

Egbe OM and Vange T 2008. Yield and Agronomic Characteristics of 30 Pigeonpea Genotypes at Otobi in Southern Guinea Savanna of Nigeria. Life Science Journal, 5: 70-80.

INDIASTAT (2014). http//=www.indiastat.com

Kumar N, Gopinath KA, Srivastva AK and Mahajan V 2008. Performance of Pigeonpea (CajanuscajanL. Millsp.) at Different Sowing Dates in the Mid-hills of Indian Himalaya. Archives of Agronomy and Soil Science, 54: 507-514.

Mligo JK and Craufurd PQ 2005.Adaptation and Yield of Pigeonpea in Different Environments in Tanzania. Field Crops Research, 94: 43-53.

Nuttonson MY 1955. Wheat climatic relationship and use of phenology in ascertaining the thermal and photothermal requirements of wheat. American Institution of Crop Ecology, Washington DC.

Patel NR, Mehta AN and Shekh AM 2000.Radiation Absorption, Growth and Yield of Pigeonpea Cultivars as Influenced by Sowing Dates. Experimental Agriculture 36 (3):291-301.

PAU 2008.Package of Practices for Crops of Punjab, Kharif 2008.Punjab Agricultural University, Ludhiana, India.

Ram H, Singh G, Sekhon H S and Khanna V 2011.Effect of Sowing Time on the Performance of Pigeonpea Geno- types. Journal of Food Legumes 24(3): 207-210.

Rani BP and Reddy DR 2010. Performance of Pigeonpea in Sole and Intercropping System in Vertisols of KrishnaGodavari Zone in Andhra Pradesh. Indian Journal of Agricultural Research 44(3): 225-228.

Rao SC, Phillips WA, Mayeux HS and Phatak SC 2003.Potential Grain and Forage Production of Early Maturing Pigeonpea in the Southern Great Plains. Crop Science 43: 2212-2217.

Reddy MM, Padmaja B and Malathi S 2012.Evaluation of Pigeonpea Genotypes for Delayed Sowing in Telangana Region of Andhra Pradesh under Rainfed Conditions. Indian Journal of Dryland Agricultural Researchand Development 27(2): 59-62.

Reddy MM, Padmaja B and Rao LJ 2006.Agronomic Management for Improving Productivity of Pigeonpea-based Intercropping System under Rainfed Conditions in Vertisols. Indian Journal of Pulses Research19: 219-221.

Singh G, Ram H, Sekhon HS, Gill KK and Khanna V 2012. Effect of Time of Planting on Nodulation, Growth and Seed Yield of Kharif Urdbean Genotypes. Journal of Food Legumes 25(2): 125-127.

Singh G, Sekhon HS, Ram H, Gill KK and Sharma P 2010. Effect of Date of Sowing on Nodulation, Growth and Grain Yield of Kharif Mungbean Genotypes. Journal of Food Legumes 23(2): 132-134.

Singh RS 2006.Performance of Late Duration Pigeonpea Varieties under Delayed Planting. Indian Journal of Pulses Research 19: 255-256.

Tomar SPS, Tomar SS and Srivastava SC 2014. Yield and Yield Component Response of Wheat (Triticum aestivum L) Genotypes to Different Sowing Dates in Gird region of Madhya Pradesh. International Journal of Farm Sciences 4(2):1-6.

Umesh MR, Shankar MA and Ananda N 2013. Yield, Nutrient Uptake and Economics of Pigeonpea (Cajanus cajan L.) Genotypes under Nutrient Supply Levels in Dryland Alfisolsof Karnataka. Indian Journal of Agronomy 58(4): 554-559.

Wilson C, Hui D, Nwaneri E, Wang J, Deng Q, Duseja D and Tegegne F 2012.Effects of Planting Dates, Densities, and Varieties on Ecophysiology of Pigeonpea of Southeastern United States. Agricultural Sciences 3(2): 147-152. 